Original Research Paper

\title{
Optimization of Hydrolysis Conditions for Obtaining Antithrombotic Peptides from Tenebrio Molitor Larvae
}

\author{
Fangyuan Chen, Han Jiang, Yini Gan, Wenwei Chen and Guangrong Huang \\ Key Lab of Marine Food Quality and Hazard Controlling Technology of Zhejiang Province, \\ College of Life Sciences, China Jiliang University, Hangzhou, China
}

\author{
Article history \\ Received: 13-02-2019 \\ Revised: $27-03-2019$ \\ Accepted: 18-05-2019 \\ Corresponding Author: \\ Guangrong Huang, \\ College of Life Sciences, \\ China Jiliang University, \\ Hangzhou, China \\ Email: grhuang@126.com
}

\begin{abstract}
Tenebrio molitor larvae was hydrolyzed by pepsin and trypsin for preparing high antithrombotic activity hydrolysate. The significant variables were selected according to the Plackett-Burman design and further optimized by the Response Surface Methodology (RSM). Four factors, including substrate concentration, pepsin digestion time, pepsin amount and trypsin amount, respectively, influenced significantly on the hydrolysis effectiveness. The best hydrolysis conditions obtained using RSM experiments are as following: substrate concentration of $19.8 \mathrm{mg} / \mathrm{mL}$, pepsin digestion time of $1.8 \mathrm{~h}$, pepsin amount of $1634 \mathrm{U} / \mathrm{mL}$ and trypsin amount of $126 \mathrm{U} / \mathrm{mL}$, respectively. Under the optimal hydrolysis conditions, the antithrombotic activity was $82.8 \%$ predicted by the RSM model, which was basically consistent with the $80.6 \%$ obtained in the three verification experiments. Moreover, the antithrombotic activity of the hydrolyzate had no linear relationship with the degree of hydrolysis.
\end{abstract}

Keywords: Tenebrio molitor Larvae, Enzymatic Hydrolysis, Antithrombotic Activity, Plackett-Burman Design, Response Surface Methodology

\section{Introduction}

Thromboembolic diseases include disseminated intravascular coagulation, deep vein thrombosis, transient ischemic attack and pulmonary embolism, which are serious diseases that threaten human health and even cause death (Wakefield et al., 2008). According to statistics, the incidence of venous thromboembolism per 1,000 people in industrialized countries was 1-3 cases per year (Heit et al., 2005). Thrombosis is usually caused by abnormal blood clots in the circulating blood, or by blood deposits on the inner wall of the heart or blood vessels (Mackman, 2012). The development of blood clots involves the complex interaction of vascular endothelium, platelets and coagulation factors (Syed and Mehta, 2018). Currently, antithrombotics such as heparin, warfarin are most often used for treatment (Einhäupl et al., 1991, Prasad et al., 2009). However, it's gradually found that the long-term use of these drugs can cause severe bleeding in the clinical application (Levine et al., 2001; Prasad et al., 2009). In addition, gastrointestinal system injury (Derry and Loke, 2000; Grossman, 2015; Kkf et al., 2018), drug-induced thrombocytopenia (Abraham, 2011) and fetal malformation (Schivazappa et al., 1982) are also common adverse reactions. Therefore, it is the objective to find the antithrombotic agent which is safer and effective.

During the past three decades, various peptides have been separated and identified from natural substances and have exhibited many bioactive functions (Lima and Moraes, 2018). Nowadays, vary of peptides or hydrolysates of protein derived from the insects (especially the hematophagous and venomous insects) have been shown to have antithrombotic activity in vitro. Peptides derived from insects bind to coagulation factors through the molecular interaction in the intrinsic pathway or extrinsic pathway of blood coagulation (Syed and Mehta, 2018). In addition, there are some researchers found that they can also antagonize platelet membrane glycoprotein integrin and prevent platelet aggregation (Ciprandi et al., 2003).

Generally, proteins are cleaved into smaller active peptides or free amino acids using enzymatic hydrolysis. These low sequence peptides often contain original functional activities compared to the original protein. The yellow mealworms (Tenebrio molitor), belong to the family of Tenebrionidae, are used to be considered pests due to their eating habits (Tang et al., 2018). However, these larvae have a protein content of more than $25 \%$ (fresh weight) that considered as the extremely rich 
protein resource. Rich protein of $T$. molitor may produce various bioactivity peptides after enzymatic hydrolysis. Recently, pepsin and trypsin have been used as commonly used enzymes for protein hydrolysis to obtain antithrombotic peptides. (Qiao et al., 2018; Tian et al., 2016). Compared with plant proteases, pepsin and trypsin have high hydrolysis rates and short reaction cycles. Moreover, the enzymatic hydrolysates obtained by simulating biological functions are more suitable for functioning in living organisms (Huang et al., 2009). In our previous preparations, it was found that enzymatic hydrolysis gave the degree of hydrolysis of $21.5 \%$ and an anticoagulant activity of $60.78 \%$ (Csample $=30$ $\mathrm{mg} / \mathrm{mL}$ ) under gastrointestinal conditions. Therefore, in the present study, we optimized the enzymatic hydrolysis conditions of $T$. molitor larvae with pepsin and trypsin in order to obtain the higher proteolytic and antithrombotic peptides.

\section{Materials and Methods}

\section{Materials}

T. molito larvae were bought from a local flower and bird market in Hangzhou, China and were brought to the laboratory in a living state. The species of the $T$. molitor was identified by observation and comparison of morphology. Bovine fibrinogen and thrombin were purchased from Sigma. The pepsin $(3000 \mathrm{U} / \mathrm{mg})$ and trypsin $(250 \mathrm{U} / \mathrm{mg})$ were of biochemical grade and purchased from local chemical company. And other chemicals used in this experiment were of analytical grade without special mention.

The T. molitor larvae were starved for $24 \mathrm{~h}$ to empty the intestines and then washed several times with distilled water. They were then dried at $50^{\circ} \mathrm{C}$ until the moisture content was reached 5\%. The dry insects were ground into a powder with the stirrer (Tang et al., 2018). T. molitor powder was degreased by isopropyl alcohol at $50^{\circ} \mathrm{C}$ for $1 \mathrm{~h}$. The defatted T. molitor slurry was dried and stored at $-20^{\circ} \mathrm{C}$.

\section{Preparation of Hydrolysate}

The main operation of the enzymatic hydrolysate for preparing the T. molitor larvae protein was as follows. The $\mathrm{pH}$, incubation time and enzyme amounts were set according to experiment design shown in corresponding tables. The defatted T. molitor powder was suspended in distilled water and adjusted to designated $\mathrm{pH}$. The requisite amount of pepsin solution was added and started to hydrolysis at oscillation water bath. At the end of pepsin hydrolysis, adjust $\mathrm{pH}$ to a certain value with 1 $\mathrm{M} \mathrm{NaOH}$ and the trypsin was added, incubating with agitation during a period of time. After that, protease activity was stopped by heating at $95^{\circ} \mathrm{C}$ for $15 \mathrm{~min}$. Finally, the mixture was centrifuged at $12000 \times \mathrm{g}$ for 15 min and the supernatant was collected.

\section{Determination of the Degree of Hydrolysis (DH)}

The DH was tested by the method of Balson and Lawson (1936) with a little modification. The method is based on free amino groups combined with formaldehyde and releasing $\mathrm{H}^{+}$from free amino groups. The amount of free amino groups can be calculated by titrating the released $\mathrm{H}^{+}$with the alkali. The hydrolysis process is mainly the cleavage of peptide bonds, resulting in the formation of free amino groups. Therefore, the degree of hydrolysis can be obtained by calculating the change in the content of the free amino group before and after the hydrolysis. Simply, $8 \mathrm{~mL}$ hydrolysate was diluted with $60 \mathrm{~mL}$ distilled water and adjusted the $\mathrm{pH} 7$. After then, $10 \mathrm{~mL}$ neutral formaldehyde solution was added and stirred constantly for 5 mins. The solution was then titrated to $\mathrm{pH} 9.2$ with a $0.05 \mathrm{M} \mathrm{NaOH}$ standard solution and the consumption volume of $\mathrm{NaOH}$ was recorded as $\mathrm{V}_{1}(\mathrm{~mL})$. Repeated the above steps, taking the unhydrolyzed protein solution as a blank experiment and noted that $\mathrm{NaOH}$ consumption volume as $\mathrm{V}_{2}(\mathrm{~mL})$. Protein content was determined using the K1100 automatic Kjeldahl analyzer (Hanon, Shandong, China). And the protein conversion factor was 6.25 .

The DH value was expressed as the Equation 1:

$D H \%=0.05 \times\left(V_{1}-V_{2}\right) \times\left(1000 / 8 C_{w o}\right) \times(1 / 6.25) \times 100$

where, $C_{\mathrm{wo}}$ is the protein concentration of the sample solution $(\mathrm{g} / \mathrm{L})$.

\section{Determination of Antithrombotic Activity}

Antithrombotic activity was determined according to the method of Yang et al. (2007). Samples, thrombin and fibrinogen were separately dissolved in $0.05 \mathrm{~mol} / \mathrm{L}$ Tris$\mathrm{HCl}$ buffer $(\mathrm{pH} 7.4)$. The absorbance was measured at $405 \mathrm{~nm}$ using the IMark microplate reader (Uji-shi, Kyoto, Japan). $140 \mu \mathrm{L}$ of $1 \mathrm{mg} / \mathrm{mL}$ fibrinogen and $40 \mu \mathrm{L}$ of the sample were added to the 96 microplate well, mixed and the absorbance $S b$ was recorded. Then, $10 \mu \mathrm{L}$ of thrombin $(12 \mathrm{IU} / \mathrm{mL})$ was added to the well at $37^{\circ} \mathrm{C}$ for $10 \mathrm{~min}$ and the value was $\mathrm{S}$. The control group contained $40 \mu \mathrm{L}$ of Tris-HCl buffer instead of the sample and the absorbances were $C b$ and $C$, respectively. The antithrombotic activity was expressed as the Equation 2:

Antithrombotic activity $(\%)=\frac{\left(C-C_{b}\right)-\left(S-S_{b}\right)}{C-C_{b}} \times 100$ 


\section{Selection of Significant Variables by Plackett- Burman Design}

In the previous experiment, it was confirmed that the hydrolysate with antithrombotic activity could be obtained by hydrolyzing the protein of the mealworm with pepsin and trypsin. A total of nine parameters were tested and identified by the Plackett-Burman Design (PBD) to select significant variables for proteolysis. Each factor had a low level and a high level, where $\mathrm{X}_{10}$ and $X_{11}$ were the comparative virtual factors set by the estimation error (Table 1). Proteolysis had a significant effect on factors above $95 \%$ confidence level $(\mathrm{P}<0.05)$. The first-order polynomial model was used for mathematical modeling as follows (Dayana and Bakthavatsalam, 2016):

$$
Y=\beta_{0}+\sum \beta_{i} x_{i}
$$

where, $Y$ is the predicted response (DH of proteolysis), $\beta_{0}$ is the model intercept and $\beta_{i}$ is the linear coefficient and $x_{\mathrm{i}}$ is the level of the independent variable.

\section{Optimization by Response Surface Methodology (RSM)}

The Execution Factor Box-Behnken Design (BBD) was used to determine the optimal value for each variable to achieve maximum antithrombotic activity after PBD screening. In this study, a four-independentfactor-three-level BBD was employed with 29 runs. The four significant factors were substrate concentration $(\mathrm{mg} / \mathrm{mL})$, pepsin digestion time (h), pepsin amount $(\mathrm{U} / \mathrm{mL})$ and trypsin amount $(\mathrm{U} / \mathrm{mL})$ which were denoted as $X_{1}, X_{2}, X_{3}$ and $X_{4}$ respectively (Table 2 ). At the same time, other non-critical factors were fixed: Pepsin reaction $\mathrm{pH} 2.0$, pepsin reaction temperature $37^{\circ} \mathrm{C}$, trypsin digestion time $5 \mathrm{~h}$, trypsin reaction $\mathrm{pH} 8$, trypsin reaction temperature was $37^{\circ} \mathrm{C}$. After enzymatic hydrolysis process, the mixture was centrifuged at $12000 \times \mathrm{g}$ for $15 \mathrm{~min}$. The supernatant was used to determination the antithrombotic activity and $\mathrm{DH}$.

The antithrombotic activity and DH data were fitted by a multiple regression program (Equation 4):

$$
Y=a_{0}+\sum_{i=1}^{k} a_{i} x_{i}+\sum_{i=1}^{k} a_{i i} x_{i}^{2}+\sum_{i=1}^{k} \sum_{j=1}^{k} a_{i j} x_{i} x_{j}+e_{0}
$$

where, $Y$ is predicted value, $k$ is the amount of factors, $\alpha_{0}$ is the intercept, $\alpha_{i}, \alpha_{i i}$ and $\alpha_{i j}$ are coefficients of the model. $x_{i}$ or $x_{j}$ are the coded factors.

\section{Statistical Analysis}

Experimental data were analyzed by ANOVA. The statistical software package Design-Expert V 8.0.6 (StatEase, Inc., Minneapolis, MN, USA) was used for statistical analysis of PBD and RSM.

\section{Results}

\section{Screening of Significant Factors Using PBD}

The PBD was used to select the significant variables necessary to enhance DH in this study. Factors above the $95 \%$ confidence level are considered to have a significant effect on the outcome and apply to the next optimization phase. The results (Table 3 ) showed that the effect of substrate concentration $(\mathrm{mg} / \mathrm{mL})$, pepsin digestion time (h), pepsin amount $(\mathrm{U} / \mathrm{mL})$ and trypsin amount $(\mathrm{U} / \mathrm{mL})$ have a positive influence on proteolysis and hence were further determined by an RSM design.

The model equation for $\mathrm{DH}(Y, \%)$ was as follows:

\begin{tabular}{|c|c|c|c|c|c|c|c|c|c|c|c|c|c|}
\hline \multirow[b]{2}{*}{ Run order } & \multicolumn{11}{|c|}{ Coded levels ${ }^{\mathrm{a}}$} & \multicolumn{2}{|l|}{ DH (\%) } \\
\hline & $\mathrm{X}_{1}$ & $\mathrm{X}_{2}$ & $\mathrm{X}_{3}$ & $\mathrm{X}_{4}$ & $\mathrm{X}_{5}$ & $\mathrm{X}_{6}$ & $\mathrm{X}_{7}$ & $\mathrm{X}_{8}$ & $\mathrm{X}_{9}$ & $\mathrm{X}_{10}$ & $\mathrm{X}_{11}$ & Observed $^{\mathrm{b}}$ & Predicted \\
\hline 1 & 30 & 2.5 & 1000 & 2.5 & 40 & 5.00 & 100 & 7.5 & 35 & 1 & -1 & 4.50 & 5.19 \\
\hline 2 & 5 & 2.5 & 2500 & 2.0 & 40 & 5.00 & 250 & 7.5 & 35 & -1 & 1 & 23.75 & 23.06 \\
\hline 3 & 30 & 1.0 & 2500 & 2.5 & 35 & 5.00 & 250 & 8.0 & 35 & -1 & -1 & 13.03 & 13.51 \\
\hline 4 & 5 & 2.5 & 1000 & 2.5 & 40 & 3.33 & 250 & 8.0 & 40 & -1 & -1 & 14.40 & 14.89 \\
\hline 5 & 5 & 1.0 & 2500 & 2.0 & 40 & 5.00 & 100 & 8.0 & 40 & 1 & -1 & 9.98 & 10.67 \\
\hline 6 & 5 & 1.0 & 1000 & 2.5 & 35 & 5.00 & 250 & 7.5 & 40 & 1 & 1 & 16.23 & 15.75 \\
\hline 7 & 30 & 1.0 & 1000 & 2.0 & 40 & 3.33 & 250 & 8.0 & 35 & 1 & 1 & 5.91 & 5.43 \\
\hline 8 & 30 & 2.5 & 1000 & 2.0 & 35 & 5.00 & 100 & 8.0 & 40 & -1 & 1 & 6.28 & 5.59 \\
\hline 9 & 30 & 2.5 & 2500 & 2.0 & 35 & 3.33 & 250 & 7.5 & 40 & 1 & -1 & 12.80 & 13.49 \\
\hline 10 & 5 & 2.5 & 2500 & 2.5 & 35 & 3.33 & 100 & 8.0 & 35 & 1 & 1 & 15.12 & 14.64 \\
\hline 11 & 30 & 1.0 & 2500 & 2.5 & 40 & 3.33 & 100 & 7.5 & 40 & -1 & 1 & 1.40 & 0.71 \\
\hline 12 & 5 & 1.0 & 1000 & 2.0 & 35 & 3.33 & 100 & 7.5 & 35 & -1 & -1 & 6.94 & 7.42 \\
\hline
\end{tabular}

Table 1: Plackett-burman design of factors (in coded levels) with proteolysis as response

${ }^{\mathrm{a}}$ The meaning of each code representative: $\mathrm{X}_{1}$ :Substrate concentration $(\mathrm{mg} / \mathrm{mL}), \mathrm{X}_{2}$ :Pepsin digestion time $(\mathrm{h}), \mathrm{X}_{3}:$ Pepsin amount $(\mathrm{U} / \mathrm{mL}), \mathrm{X}_{4}$ :Pepsin reaction $\mathrm{pH}, \mathrm{X}_{5}$ :Pepsin reaction temperature $\left({ }^{\circ} \mathrm{C}\right), \mathrm{X}_{6}$ :Trypsin digestion time $(\mathrm{h}), \mathrm{X}_{7}:$ Trypsin amount $(\mathrm{U} / \mathrm{mL})$, $\mathrm{X}_{8}$ :Trypsin reaction $\mathrm{pH}, \mathrm{X}_{9}$ :Trypsin reaction temperature $\left({ }^{\circ} \mathrm{C}\right), \mathrm{X}_{10}, \mathrm{X}_{11}$ :Virtual factor; ${ }^{\mathrm{b}}$ The observed values of DH were the mean values of duplicates.

${ }^{\mathrm{b}}$ The observed values of DH were the mean values of duplicates. 
Table 2: Experimental design and results of BBD

\begin{tabular}{|c|c|c|c|c|c|c|c|c|}
\hline \multirow[b]{2}{*}{ Run order } & \multicolumn{4}{|c|}{ Coded levels ${ }^{\mathrm{a}}$} & \multicolumn{2}{|l|}{$\mathrm{DH}(\%)$} & \multicolumn{2}{|c|}{ Antithrombotic activity (\%) } \\
\hline & $\mathrm{X}_{1}$ & $X_{2}$ & $X_{3}$ & $\mathrm{X}_{4}$ & Observed $^{\mathrm{b}}$ & Predicted & Observed $^{\mathrm{b}}$ & Predicted \\
\hline 1 & 5 & 1 & 1750 & 175 & 5.94 & 5.89 & 46.23 & 45.42 \\
\hline 2 & 30 & 1 & 1750 & 175 & 6.06 & 6.38 & 38.67 & 37.08 \\
\hline 3 & 5 & 2.5 & 1750 & 175 & 19.70 & 19.50 & 40.93 & 40.19 \\
\hline 4 & 30 & 2.5 & 1750 & 175 & 0.77 & 0.95 & 59.96 & 58.44 \\
\hline 5 & 17.5 & 1.75 & 1000 & 100 & 8.90 & 9.26 & 62.40 & 61.35 \\
\hline 6 & 17.5 & 1.75 & 2500 & 100 & 6.50 & 6.36 & 74.33 & 74.79 \\
\hline 7 & 17.5 & 1.75 & 1000 & 250 & 7.05 & 7.32 & 54.48 & 51.69 \\
\hline 8 & 17.5 & 1.75 & 2500 & 250 & 3.67 & 3.44 & 41.91 & 40.63 \\
\hline 9 & 5 & 1.75 & 1750 & 100 & 19.30 & 19.27 & 53.55 & 52.46 \\
\hline 10 & 30 & 1.75 & 1750 & 100 & 3.22 & 2.52 & 81.90 & 83.15 \\
\hline 11 & 5 & 1.75 & 1750 & 250 & 8.38 & 9.12 & 56.51 & 56.28 \\
\hline 12 & 30 & 1.75 & 1750 & 250 & 7.76 & 7.82 & 33.39 & 35.50 \\
\hline 13 & 17.5 & 1 & 1000 & 175 & 5.09 & 5.54 & 30.81 & 31.44 \\
\hline 14 & 17.5 & 2.5 & 1000 & 175 & 8.39 & 8.03 & 56.04 & 58.46 \\
\hline 15 & 17.5 & 1 & 2500 & 175 & 0.14 & 0.55 & 52.99 & 51.59 \\
\hline 16 & 17.5 & 2.5 & 2500 & 175 & 6.65 & 6.24 & 40.30 & 40.70 \\
\hline 17 & 5 & 1.75 & 1000 & 175 & 17.97 & 17.46 & 59.69 & 60.86 \\
\hline 18 & 30 & 1.75 & 1000 & 175 & 11.75 & 11.54 & 48.93 & 48.54 \\
\hline 19 & 5 & 1.75 & 2500 & 175 & 17.14 & 17.18 & 43.08 & 44.77 \\
\hline 20 & 30 & 1.75 & 2500 & 175 & 4.70 & 5.04 & 66.88 & 67.01 \\
\hline 21 & 17.5 & 1 & 1750 & 100 & 0.56 & 0.34 & 52.39 & 53.53 \\
\hline 22 & 17.5 & 2.5 & 1750 & 100 & 5.29 & 6.03 & 63.31 & 62.59 \\
\hline 23 & 17.5 & 1 & 1750 & 250 & 0.42 & -0.49 & 30.58 & 32.61 \\
\hline 24 & 17.5 & 2.5 & 1750 & 250 & 1.95 & 2.00 & 39.52 & 39.68 \\
\hline 25 & 17.5 & 1.75 & 1750 & 175 & 28.09 & 28.37 & 78.24 & 79.23 \\
\hline 26 & 17.5 & 1.75 & 1750 & 175 & 28.18 & 28.37 & 79.66 & 79.23 \\
\hline 27 & 17.5 & 1.75 & 1750 & 175 & 28.85 & 28.37 & 79.44 & 79.23 \\
\hline 28 & 17.5 & 1.75 & 1750 & 175 & 28.37 & 28.37 & 78.46 & 79.23 \\
\hline 29 & 17.5 & 1.75 & 1750 & 175 & 28.35 & 28.37 & 80.35 & 79.23 \\
\hline
\end{tabular}

${ }^{a}$ The meaning of each code representative: $\mathrm{X}_{1}$ :Substrate concentration $(\mathrm{mg} / \mathrm{mL}), \mathrm{X}_{2}:$ Pepsin digestion time (h), $\mathrm{X}_{3}:$ Pepsin amount $(\mathrm{U} / \mathrm{mL}), \mathrm{X}_{4}$ :Trypsin amount $(\mathrm{U} / \mathrm{mL})$

${ }^{\mathrm{b}}$ The observed values of $\mathrm{DH}$ and antithrombotic activity were the mean values of duplicates.

Table 3: Effect and statistical analysis of factors using PBD

\begin{tabular}{llcccc}
\hline Variables & Coefficient & \%Contribution & Standard error & Sum of squares & P-value \\
\hline Intercept & 10.86 & - & - & - & - \\
Model & - & - & - & 421.44 & $0.0443^{* *}$ \\
$\mathrm{X}_{1}$ & -3.54 & 35.36 & 0.42 & 150.52 & $0.0139^{* *}$ \\
$\mathrm{X}_{2}$ & 1.95 & 10.68 & 0.42 & 45.47 & $0.0438^{* *}$ \\
$\mathrm{X}_{3}$ & 1.82 & 9.32 & 0.42 & 39.68 & $0.0497^{* *}$ \\
$\mathrm{X}_{4}$ & -0.082 & 0.019 & 0.42 & 0.080 & 0.8642 \\
$\mathrm{X}_{5}$ & -0.87 & 2.14 & 0.42 & 9.12 & 0.1745 \\
$\mathrm{X}_{6}$ & 1.43 & 5.79 & 0.42 & 24.65 & 0.0766 \\
$\mathrm{X}_{7}$ & 3.49 & 34.37 & 0.42 & 146.30 & $0.0143^{* *}$ \\
$\mathrm{X}_{8}$ & -0.075 & 0.016 & 0.42 & 0.067 & 0.8751 \\
$\mathrm{X}_{9}$ & -0.68 & 1.3 & 0.42 & 5.55 & 0.2480 \\
\hline $\mathrm{R}^{2}-0.9900 ; \mathrm{Adjus}$ & -2.95 &
\end{tabular}

$\mathrm{R}^{2}-0.9900$; Adjusted-R ${ }^{2}-0.9449$; Adeq precisior-16.771; 95\% significant level. ** Significant at $\mathrm{P}<0.05$

$$
\begin{aligned}
Y & =18.07328-0.28333 X_{1}+2.59556 X_{2}+2.42444 \\
& \times 10^{-3} X_{3}-0.32667 X_{4}-0.34867 X_{5}+1.71657 X_{6} \\
& +0.046556 X_{7}-0.30000 X_{8}-0.27200 X_{9}
\end{aligned}
$$

The $P$ value of the analysis of variance model was 0.0443 and the adjeq precision was $16.271>4$ indicating that the regression region of the model fits well and is satisfactory. $R^{2}=0.9900$ and $\operatorname{Adj} R^{2}=0.9449$, indicating that the regression model can account for $94.5 \%$.

\section{Optimization by RSM}

The experiments conducted in this study consisted of a quadratic model consisting of 29 trials. The corresponding results and predicted values of the RSM experiments for the four variables (substrate concentration, pepsin digestion time, pepsin amount and trypsin amount) were shown in Table 2. Table 4 showed the variance analysis of the response surface quadratic model. 
Table 4: ANOVA for antithrombotic activity

\begin{tabular}{|c|c|c|c|c|c|}
\hline \multirow[b]{2}{*}{ Source } & \multirow[b]{2}{*}{ Sum of Squares } & \multirow[b]{2}{*}{$\mathrm{df}$} & \multirow[b]{2}{*}{ Mean Square } & \multirow[b]{2}{*}{ F Value } & \multirow{2}{*}{$\begin{array}{l}\text { p-value } \\
\text { Prob>F }\end{array}$} \\
\hline & & & & & \\
\hline Model & 7282.678000 & 14 & 520.191300 & 158.651700 & $<0.0001^{* *}$ \\
\hline $\mathrm{X}_{1}$-Substrate concentration & 73.674760 & 1 & 73.674760 & 22.469860 & $0.0003^{*}$ \\
\hline $\mathrm{X}_{2}$-Pepsin digestion time & 195.233300 & 1 & 195.233300 & 59.543660 & $<0.0001 * *$ \\
\hline $\mathrm{X}_{3}$-Pepsin amount & 4.253434 & 1 & 4.253434 & 1.297243 & 0.2738 \\
\hline $\mathrm{X}_{7}$-Trypsin amount & 1440.768000 & 1 & 1440.768000 & 439.415900 & $<0.0001 * *$ \\
\hline $\mathrm{X}_{1} \mathrm{X}_{2}$ & 176.692900 & 1 & 176.692900 & 53.889060 & $<0.0001 * *$ \\
\hline $\mathrm{X}_{1} \mathrm{X}_{3}$ & 298.484500 & 1 & 298.484500 & 91.033950 & $<0.0001 * *$ \\
\hline $\mathrm{X}_{1} \mathrm{X}_{7}$ & 662.287900 & 1 & 662.287900 & 201.989400 & $<0.0001 * *$ \\
\hline $\mathrm{X}_{2} \mathrm{X}_{3}$ & 359.338700 & 1 & 359.338700 & 109.593700 & $<0.0001 * *$ \\
\hline $\mathrm{X}_{2} \mathrm{X}_{7}$ & 0.983260 & 1 & 0.983260 & 0.299882 & 0.5926 \\
\hline $\mathrm{X}_{3} \mathrm{X}_{7}$ & 150.125300 & 1 & 150.125300 & 45.786300 & $<0.0001 * *$ \\
\hline$X_{1}^{2}$ & 949.570400 & 1 & 949.570400 & 289.606800 & $<0.0001 * *$ \\
\hline$X_{2}^{2}$ & 3096.076000 & 1 & 3096.076000 & 944.263700 & $<0.0001 * *$ \\
\hline$X_{3}^{2}$ & 908.216100 & 1 & 908.216100 & 276.994300 & $<0.0001 * *$ \\
\hline$X_{7}^{2}$ & 685.372900 & 1 & 685.372900 & 209.030000 & $<0.0001 * *$ \\
\hline Residual & 45.903560 & 14 & 3.278826 & & \\
\hline Lack of Fit & 42.865600 & 10 & 4.286560 & 5.644000 & 0.0549 \\
\hline Pure Error & 3.037959 & 4 & 0.759490 & & \\
\hline Cor Total & 7328.582000 & 28 & & & \\
\hline
\end{tabular}

* Significant at $\mathrm{P} \leq 0.05$

$* *$ Significant at $\mathrm{P} \leq 0.01$

The model $F$ value of 158.65 indicated that the model was significant $(\mathrm{P}<0.001)$. A "lack of fitted $\mathrm{F}$ value" of 0.055 indicates that the model was well suited. $X_{1}$, $\mathrm{X}_{2}, \mathrm{X}_{4}, \mathrm{X}_{1} \mathrm{X}_{2}, \mathrm{X}_{1} \mathrm{X}_{3}, \mathrm{X}_{1} \mathrm{X}_{4}, \mathrm{X}_{2} \mathrm{X}_{3}, \mathrm{X}_{3} \mathrm{X}_{4}, X_{1}^{2}, X_{2}^{2}$, $X_{3}^{2}$ and $X_{4}^{2}$ were shown to be significant by ANOVA analysis $(\mathrm{P}<0.05)$. The coefficient of $\mathrm{R}^{2}$ is equal to 0.9937 indicating that the model has good accuracy. The anti-thrombotic activity of $R^{2}\left(\mathrm{ad}_{\mathrm{j}}\right)$ was 0.9875 , indicating that the model can account for $98.75 \%$ of the antithrombotic activity. This pattern does not account for $1.25 \%$ of the total variation.

The following regression equation indicated antithrombotic activity (Y):

$$
\begin{aligned}
Y(\%) & =252.28552+2.45725 X_{1}+159.94138 X_{2} \\
& +0.10684 X_{3}+0.939717 X_{4}+0.70894 X_{1} X_{2} \\
& +9.21424 \times 10^{-4} X_{1} X_{3}-0.013725 X_{1} X_{4} \\
& -0.016850 X_{2} X_{3}-8.81418 \times 10^{-3} X_{2} X_{4} \\
& -1.08912 \times 10^{-4} X_{3} X_{4}-0.077435 X_{1}^{2}-38.83994 X_{2}^{2} \\
& -2.10362 \times 10^{-5} X_{3}^{2}-1.82741 \times 10^{-3} X_{4}^{2}
\end{aligned}
$$

Construct a three-dimensional response surface by plotting the Z-axis response (antithrombotic activity) against any two independent variables while keeping the other variables at zero, in order to determine the optimal value for each variable (for maximum antithrombotic activity) (Fig. 1). The antithrombotic activity increased until substrate concentration, pepsin digestion time, pepsin amount (even if not significant) and trypsin amount reached a maximum point and then decreased following further these factors increase.

The predicted model obtains the optimal hydrolysis conditions as follows: substrate concentration of 19.8 $\mathrm{mg} / \mathrm{mL}$, pepsin digestion time of $1.8 \mathrm{~h}$, pepsin amount of $1633.7 \mathrm{U} / \mathrm{mL}$ and trypsin amount of $126.5 \mathrm{U} / \mathrm{mL}$. The highest antithrombotic activity by the predicted model was $82.8 \%$. Based on these, we chose substrate concentration of $19.8 \mathrm{mg} / \mathrm{mL}$, pepsin digestion time of $1.8 \mathrm{~h}$, pepsin amount of $1634 \mathrm{U} / \mathrm{mL}$ and trypsin amount of $126 \mathrm{U} / \mathrm{mL}$ as a condition of hydrolysis. which was consistent with the average of three replicates of $80.6 \%$ obtained in the validation experiments. And the $\mathrm{DH}$ was $21.5 \%$ under this condition. The antithrombotic activity of validated experiments was uniformity to that of predicted value. Therefore, the predict model for antithrombotic activity during hydrolysis might be used for preparing hydrolysate with high antithrombotic activity.

\section{Relationship of DH and Antithrombotic Activity}

During enzymatic hydrolysis, the protein peptide bonds broke and released more peptides, that is, the increase in DH during the hydrolysis process. At the same time, the molecular weight of the peptide was also reduced. On the other hand, the antithrombotic activity of the hydrolysate changed during enzymatic hydrolysis. The relationship of $\mathrm{DH}$ and antithrombotic activity was shown in Fig. 2. The linear correlation coefficient $R^{2}$ between the hydrolysate and the protein DH was 0.2951, indicating that there is no correlation between them. 
(a)

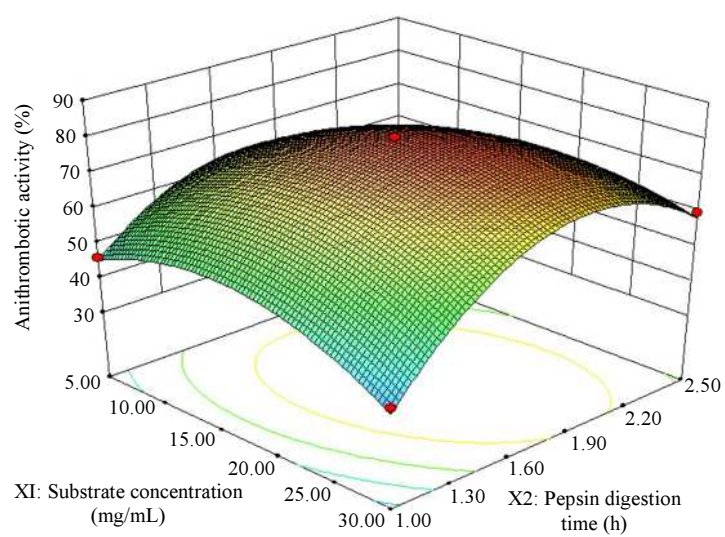

(c)
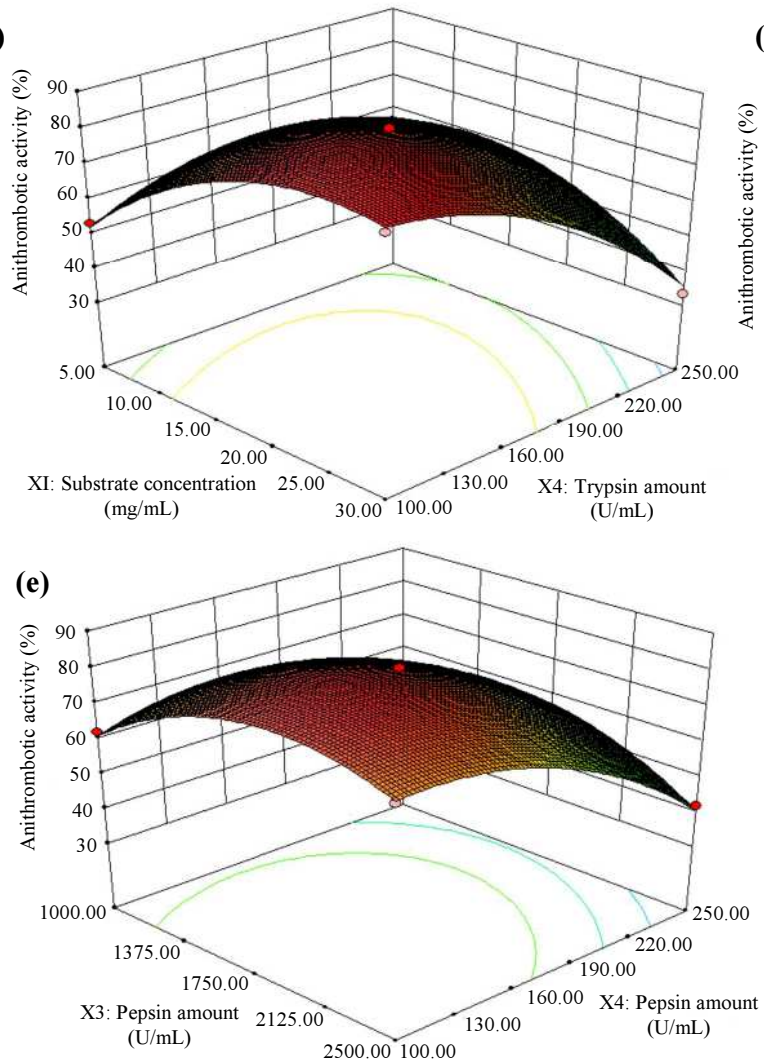

(b)
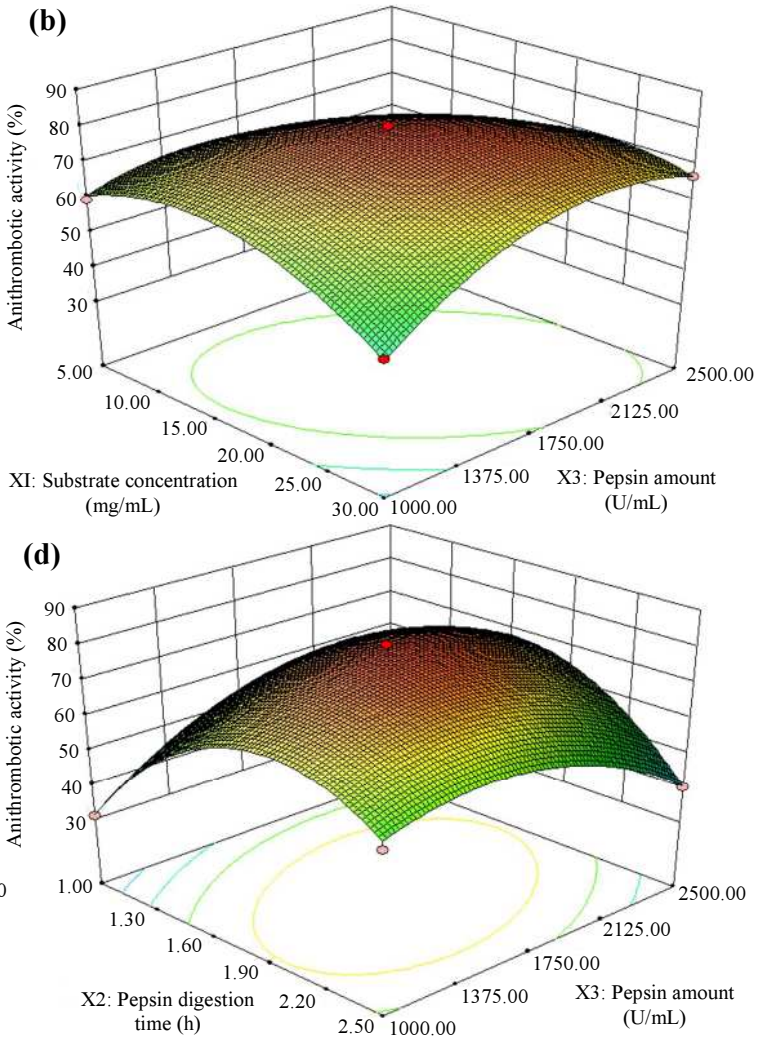

Fig. 1: The 3-D plots for the effects of variables on antithrombotic activity: (a) substrate concentration and pepsin digestion time; (b) substrate concentration and pepsin amount; (c) substrate concentration and trypsin amount; (d) pepsin digestion time and pepsin amount; (e) pepsin amount and trypsin amount.

\section{Discussion}

Peptides provide an exciting opportunity as drug candidates because they combine the benefits of small molecules (cost, compositional constraints, membrane permeability) and proteins (natural ingredients, target specificity, high potency) (Syed and Mehta, 2018). However, natural antithrombotic peptides have low yield and poor stability. Therefore, many scholars have been using specific enzymes to cleave proteins to obtain biologically active fragments. Some antithrombotic peptides by proteolytics have been confirmed in the past few years, such as Mytilus edulis, peanut and amaranth (Qiao et al., 2018; Sabbione et al., 2016; Zhang, 2016). The use of statistical models to optimize protein enzymatic conditions has increased in today's bio industry due to its ease of application and adaptability. We hope to get more antithrombotic peptides with low molecular weight and high activity. The amount and size of the protein that is cleaved into a polypeptide is positively correlated with DH (Zhang et al., 2016). 


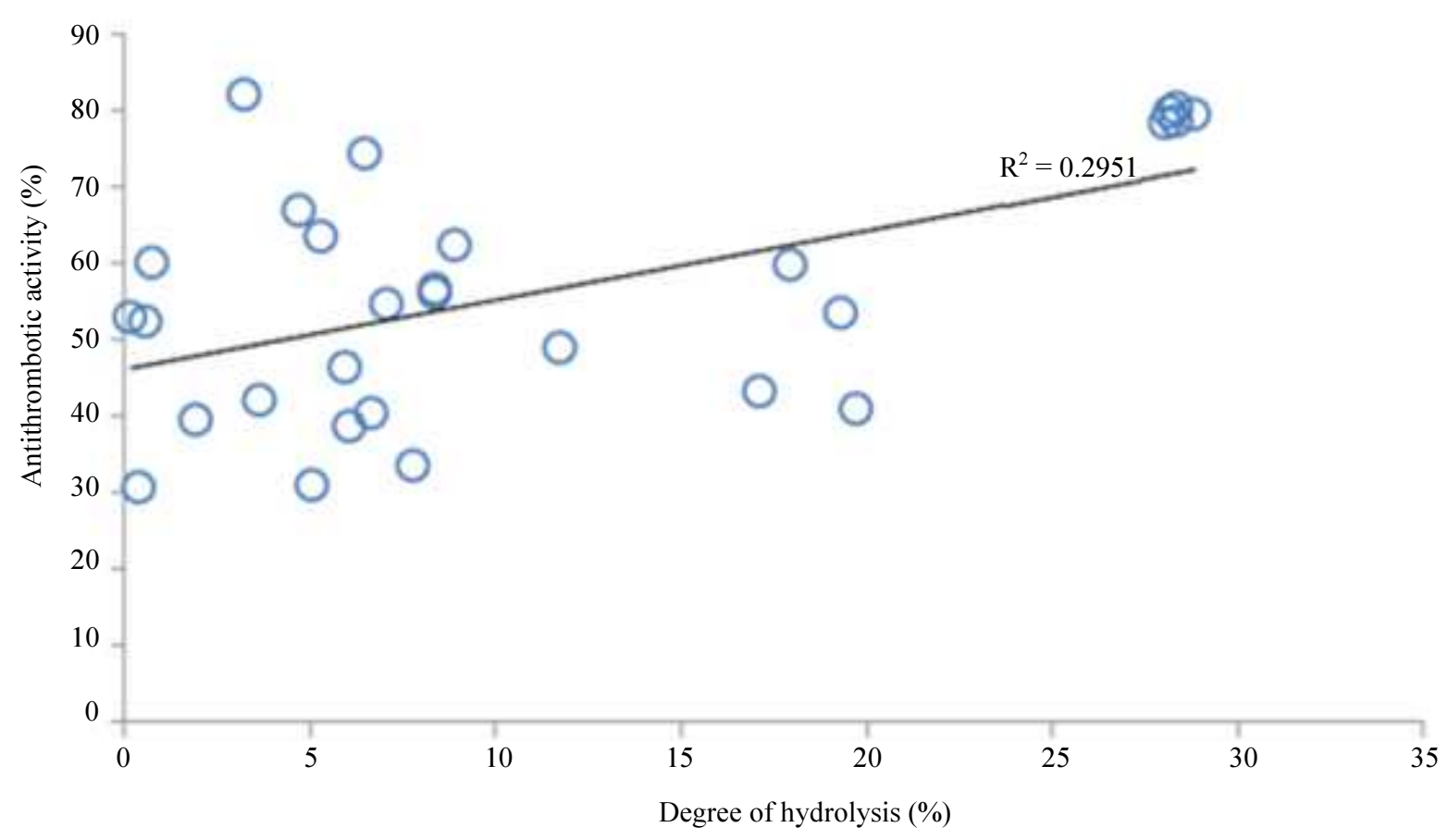

Fig. 2: The relationships of antithrombotic activity and degree of hydrolysis (DH)

Substrate concentration and digestion time are common factors affecting the activity of hydrolyzed peptides (Roslan et al., 2015; Zhang et al., 2015). The antithrombotic activity for protein hydrolyzates may be related to the amino acid end of the active peptide is arginine (Rogozinskaya and Lyapina, 2017). Arginine has been identified in many natural or synthetic antithrombotic peptides (Jo and Kim, 2008; Qiao et al., 2018). Trypsin specifically cleaves the peptide bond amount of arginine carboxy formed, forming a polypeptide having a terminal arginine. Qiao et al. (2018) used trypsin to hydrolyze Mytilus edulis protein to obtain a hydrolysate with an $\mathrm{IC}_{50}$ of $1.49 \mathrm{mg} / \mathrm{mL}$. Conversely, although the amount of pepsin significantly affected $\mathrm{DH}$, there was no significant effect on anticoagulant activity. It may be that pepsin acts on a specific site of the protein due to selectivity, resulting in no significant effect of the resulting crude peptide against thrombogenic activity (Zhang, 2016). Generally, the substrate cannot be fully enzymatically interpreted for antithrombotic activity at low levels. And at high levels, the active hydrolysate is excessively hydrolyzed and the activity is reduced. At higher substrate concentrations, due to the certain phenomena, such as changes in the fluidity of the solution, the enzyme is not sufficiently contacted with the substrate, resulting in reduced hydrolysate activity (Guerard et al., 2002). Therefore, we can find the optimal hydrolysis conditions through the RSM. Amaranth protein was hydrolyzed by simulating gastrointestinal digestion showing a doseresponse behavior $\left(\mathrm{IC}_{50}=0.23 \pm 0.02 \mathrm{mg} / \mathrm{mL}\right)$ exhibited inhibition of thrombin activity (Sabbione et al., 2016). And the DH of amaranth hydrolysate about $51.1 \%$ was much higher than T. molito larvae hydrolysate by treated with the same enzyme, probably because of the different number of restriction sites for different proteins.

After the T. molitor protein is hydrolyzed, some of the active peptide sequences originally buried in the protein molecule was released upon hydrolysis. In general, a high degree of hydrolysis makes it more likely to obtain more short peptides. The information collected in the literature indicates that peptides with antithrombotic activity are often short (Hyun et al., 2006; Sabbione et al., 2016), although some of the peptides described have higher molecular weights (Jo and Kim, 2008). Notably, there is no obvious the relationship between antithrombotic activity and degree of hydrolysis. That is, the inhibition rate corresponding to high hydrolysis degree is not necessarily the highest. In fact, when the degree of hydrolysis is low, the proteolysis is incomplete, which may result in the partial hydrolysis of the polypeptide with stronger anticoagulant activity; and excessive hydrolysis may cause the partial anticoagulant activity of the polypeptide to be hydrolyzed to peptide, causing the weakening of anticoagulant activity. Similar results have been reported in previous surveys (Zhang, 2016). 


\section{Conclusion}

This study aimed to optimize the parameters in various enzymatic processes, including substrate concentration, pepsin digestion time, pepsin amount and trypsin amount, for obtaining high antithrombotic peptides. The nine variables were tested using the PBD and four variables (i.e., substrate concentration, pepsin digestion time, pepsin amount and trypsin amount) exerted significant effects on DH. In order to optimize low cost and high efficiency enzymatic conditions for high antithrombotic peptides, we conducted RSM experiments. The optimal level of each parameter was as follows: substrate concentration of $19.8 \mathrm{mg} / \mathrm{mL}$, pepsin digestion time of $1.8 \mathrm{~h}$, pepsin amount of 1634 $\mathrm{U} / \mathrm{mL}$ and trypsin amount of $126 \mathrm{U} / \mathrm{mL}$. Under these optimal hydrolysis conditions, the predicted antithrombotic activity was $82.8 \%$, which was consistent with the average of $80.6 \%$ of the three replicates obtained in the validation experiment. In order to improve its application as a new antithrombotic drug, future studies should base on antithrombotic peptide purification, stability of antithrombotic peptides and actual absorption in intestinal cells.

\section{Acknowledgement}

This research is supported by the Science and Technology Project of Zhejiang, Province, China [grant number LGN19C200018].

\section{Author's Contributions}

Fangyuan Chen: Performed the experiments and wrote the manuscript.

Han Jiang, Yini Gan and Wenwei Chen: Participated in partial experiments.

Guangrong Huang: Developed the idea and analyzed the data.

\section{Ethics}

The authors declare that they had no conflict of interest.

\section{References}

Abraham, S.M., 2011. Drug induced thrombocytopenia: A case report. J. Indian Medical Associat., 109: 347-347.

Balson, E.W. and A. Lawson, 1936. The potentiometric determination of polypeptides and amino-acids: The formaldehyde titration. Biochem. J., 30: 1257-1257. DOI:10.1042/bj0301257

Ciprandi, A., F. Horn and C. Termignoni, 2003. Saliva of hematophagous animals: Source of new anticoagulants. Revista Brasileira Hematol. Hemoterapia, 25: 250-262.
Dayana, P.S. and A.K. Bakthavatsalam, 2016. Optimization of phenol degradation by the microalga Chlorella pyrenoidosa using plackettburman design and response surface methodology. Bioresource Technol., 207: 150-156.

DOI: 10.1016/j.biortech.2016.01.138

Derry, S. and Y.K. Loke, 2000. Risk of gastrointestinal haemorrhage with long term use of aspirin: Metaanalysis. British Med. J., 321: 1183-1187.

DOI: $10.1136 / \mathrm{bmj} .321 .7270 .1183$

Einhäupl, K.M., A. Villringer, W. Meister, S. Mehraein and C. Garner et al., 1991. Heparin treatment in sinus venous thrombosis. Lancet, 338: 597-600. DOI: 10.1016/0140-6736(91)92019-X

Guerard, F., L. Guimas and A. Binet, 2002. Production of tuna waste hydrolysates by a commercial neutral protease preparation. J. Molecular Catalysis B Enzymatic, 19: 489-498. DOI: $10.1016 / \mathrm{S} 1381-1177(02) 00203-5$

Heit, J.A., C.E. Kobbervig, A.H. James, T.M. Petterson and K.R. Bailey et al., 2005. Trends in the incidence of venous thromboembolism during pregnancy or postpartum: A 30-year population-based study. Ann. Internal Med., 143: 697-706. DOI: 10.1097/01.ogx.0000206342.79996.a3.

Huang, N.T., Y.R. Wang, W.B. Xu, S.H. Zhao and Y.J. Zhang, 2009. Technique of bionic enzymatic method for extracting scolopendra. J. Beijing Uni. Tradit. Chinese Med., 32: 706-709. DOI: 10.1007/978-1-4020-9623-5_5

Hyun, K.W., S.C. Jeong, D.H. Lee, J.S. Park and J.S. Lee, 2006. Isolation and characterization of a novel platelet aggregation inhibitory peptide from the medicinal mushroom. Inonotus obliquus. Peptides, 27: 1173-1178. DOI: 10.1016/j.peptides.2005.10.005

Jo, H.Y. and J.S.K. Kim, 2008. Purification and characterization of a novel anticoagulant peptide from marine echiuroid worm, Urechis unicinctus. Process Biochem., 43: 179-184. DOI: $10.1016 /$ j.procbio.2007.11.011

Kkf, T., F. Chan, H.W. Hirai and S. Jjy, 2018. Risk of gastrointestinal bleeding and benefit from colorectal cancer reduction from long-term use of low dose aspirin. A retrospective study of 612,509 patients. J. Gastroenterol. Hepatol., 33: 1728-1736. DOI: 10.1111/jgh.14261

Levine, M., G. Raskob, S. Landefeld and C. Kearon, 2001. Hemorrhagic complications of anticoagulant treatment. Chest, 119: 108-121. DOI: $10.1378 /$ chest.119.1_suppl.108S

Lima, T. and C.P. Moraes, 2018. Bioactive peptides: Applications and relevance for cosmeceuticals. Cosmetics, 5: 21-30. DOI: 10.3390/cosmetics5010021 
Mackman, N., 2012. New insights into the mechanisms of venous thrombosis. J. Clin. Investigat., 122: 2331-2336. DOI: 10.1172/JCI60229

Prasad, S., M.R. Wootten, N. Kulinski and S.A. Chapman, 2009. What to do when warfarin therapy goes too far. J. Family Practice, 58: 346-352. DOI: 10.1186/1471-2296-10-49.

Qiao, M., M. Tu, H. Chen, F. Mao and C. Yu et al., 2018. Identification and in silico prediction of anticoagulant peptides from the enzymatic hydrolysates of Mytilus edulis proteins. Int. J. Molecular Sci., 19: 2100-2112. DOI: $10.3390 /$ ijms 19072100

Rogozinskaya, E.Y. and M.G. Lyapina, 2017. Anticoagulant effects of arginine-containing peptides of the glyproline family (His-Phe-Arg-TrpPro-Gly-Pro and Thr-Lys-Pro-Arg-Pro-Gly-Pro) revealed by thromboelastography. Bulletin Experimental Bio. Med., 164: 170-172. DOI: $10.1007 / \mathrm{s} 10517-017-3950-4$

Roslan, J., S.M. Kamal, K.F. Yunos and N. Abdullah. 2015. Optimization of enzymatic hydrolysis of tilapia (Oreochromis niloticus) by-product using response surface methodology. Int. Food Res. J., 22: $1117-1123$

Sabbione, A.C., A.E. Nardo, M.C. Añón and A. Scilingo, 2016. Amaranth peptides with antithrombotic activity released by simulated gastrointestinal digestion. J. Funct. Foods, 20: 204-214. DOI: 10.1016/j.jff.2015.10.015

Sabbione, A.C., S.M. Ibañez, E.N. Martínez, M.C. Añón and A.A. Scilingo, 2016. Antithrombotic and antioxidant activity of amaranth hydrolysate obtained by activation of an endogenous protease. Plant Foods Human Nutrit., 71: 174-182. DOI: $10.1007 /$ s $11130-016-0540-y$

Schivazappa, L., M. Rinaldo, P. Grella, R. Russo and U. Bortolotti. 1982. Fetal malformations caused by oral anticoagulants during pregnancy, Report of a case. Giornale Italiano Cardiol., 12: 897-900.

DOI: $10.1209 / \mathrm{epl} / \mathrm{i} 2002-00419-1$
Syed, A.A. and A. Mehta, 2018. Target specific anticoagulant peptides: A review. Int. J. Peptide Res. Therapeutics, 24: 1-12. DOI: $10.1007 / \mathrm{s} 10989-018-9682-0$

Tang, Y., T. Debnath, E.J. Choi, Y.W. Kim and J.P. Ryu et al., 2018. Changes in the amino acid profiles and free radical scavenging activities of Tenebrio molitor larvae following enzymatic hydrolysis. PLoS One, 13: e0196218-e0196218. DOI: 10.1371/journal.pone.0196218

Tian, C., J. Dou, G. Liu, P. Gao and D. Bai et al., 2016. Anticoagulant activity of different enzymatic hydrolysis parts of eupolyphaga based on pharmacodynamics in vitro. Liaon. J. Tradit. Chinese Med., 43: 1299-1301.

DOI: 10.13192/j.issn.1000-1719.2016.06.063

Wakefield, T.W., J. Caprini and A.J. Comerota, 2008. Thromboembolic diseases. Current Problems Surg., 45: 844-899. DOI: 10.1067/j.cpsurg.2008.08.002

Yang, W.G., Z. Wang and S.Y. Xu, 2007. A new method for determination of antithrombotic activity of egg white protein hydrolysate by microplate reader. Chinese Chemical Lett., 18: 449-451. DOI: $10.1016 /$ j.cclet.2007.02.014

Zhang, S.B., 2016. In vitro antithrombotic activities of peanut protein hydrolysates. Food Chem., 202: 1-8. DOI: 10.1016/j.foodchem.2016.01.108

Zhang, W., Y.N. Li, J. Zhang and G.R. Huang, 2016. Optimization of hydrolysis conditions for the production of iron-binding peptides from scad (Decapterus maruadsi) processing byproducts. Am. J. Biochem. Biotechnol., 12: 220-229. DOI: 10.3844/ajbbsp.2016.220.229

Zhang, Y., L. Ma and J. Otte, 2015. Optimization of hydrolysis conditions for production of angiotensinconverting enzyme inhibitory peptides from basa fish skin using response surface methodology. J. Aquatic Food Product Technol., 25: 684-693. DOI: $10.1080 / 10498850.2014 .919049$.a 